\title{
Cian T. McMahon, The Coffin Ship: Life and Death at Sea during the Great Irish Famine
}

\section{Thierry Robin}

\section{OpenEdition}

1 Journals

\section{Édition électronique}

URL : https://journals.openedition.org/etudesirlandaises/12144

DOI : 10.4000/etudesirlandaises. 12144

ISSN : 2259-8863

\section{Éditeur}

Presses universitaires de Caen

\section{Édition imprimée}

Date de publication : 30 décembre 2021

Pagination : 160-162

ISBN : 978-2-84133-157-0

ISSN : 0183-973X

\section{Référence électronique}

Thierry Robin, "Cian T. McMahon, The Coffin Ship: Life and Death at Sea during the Great Irish Famine », Études irlandaises [En ligne], 46-2 | 2021, mis en ligne le 17 décembre 2021, consulté le 04 novembre 2022. URL : http://journals.openedition.org/etudesirlandaises/12144; DOI : https://doi.org/10.4000/ etudesirlandaises. 12144

\section{(c) (i) (2) (2)}

Creative Commons - Attribution - Pas d'Utilisation Commerciale - Partage dans les Mêmes Conditions 4.0 International - CC BY-NC-SA 4.0

https://creativecommons.org/licenses/by-nc-sa/4.0/ 
republican dissent against aiding the war effort progressed. If in 1914 many groups mobilised to support a government they had been opposing at every turn, they also saw opportunities for politicisation. For some, the war created a new dynamic for subversion and dissent, e.g. disruption at recruitment meetings and organisation of anti-recruitment ones. If on a macro-historical scale, the 1916 Rising and its immediate aftermath irreversibly transformed Irish nationalism, it also brought the war home to an island which had not witnessed it for just over a century. It gave women of all ideological shades trained in first aid their first experience of genuine conflict. Traditional assumptions of gendered roles were toppled by the prominent participation of women in the Rising, then opposition to conscription in the last two years of the war would be the final issue unifying republicans and nationalists prior to independence. Women, already agitators or previously unorganised, were heavily and publically involved.

Female citizenship in the 1920s may have been defined by motherhood and domestic life, but the war had given Irish women prominence in the public sphere, where they had defended their interests and that of their families. The book is devoid of illustrations and aimed at an academic audience, but Walsh's prose is fluid and credible. The focus is anything but insular and arguments are well supported by scrupulous research. Until now, except for specialised studies, the multiple ways in which Irish women of all backgrounds had experienced the Great War and its aftermath had remained in the shadows of history.

Sylvie KLEINMAN

\section{Cian T. McMahon, The Coffin Ship: Life and Death at Sea during the Great Irish Famine, New York, New York University Press, 2021, 315 p.}

The Great Irish Famine has long sparked a plethora of highly sensitive debates as to the actual numbers of fatalities and as to the real more or less concerted responsibilities lying behind one of the worst tragedies that occurred in Europe in the $19^{\text {th }}$ century. As often noted, this catastrophe happened right in the middle of one of the wealthiest, most powerful empires that human history had ever known so far: the British Empire. As for now, retrospectively the coffin ship mentioned in the title has turned into a symbol, not to say a tell-tale trope, an emblematic element in history that is supposed to sum it all up and is part and parcel of that grim narrative that may turn out to be strewn with "tired clichés, half truths, and dry statistics" (as the blurb posits in the front cover). Landmark books on the subject have been published to shed light on the Irish Famine, such as Cecil Woodham-Smith's (1962) The Great Hunger: Ireland 1845-49, or Cormac Ó Gráda's 1989 seminal book entitled The Great Irish Famine, or more recently The History of the Irish Famine (vol. I: The Great Irish Famine) edited by Christine Kinealy, to name but a few amongst a wealth of studies conducted by historians searching through governmental archives 
and personal documents. It has also notably inspired a continuous prolific range of works from the hybrid object in two volumes The Irish Famine, written by Diarmaid Ferriter and Colm Tóibín in 1999 to pure fiction such as the bestseller Star of the Sea, that is the 2004 historical novel by Joseph O'Connor mentioned by McMahon himself in his conclusion (p. 238) or Grace, the grimly beautiful novel by Paul Lynch published in 2019. To be sure, this new book by McMahon manages to reconcile the contradictions displayed and engendered by the conflictual memories of the crossing of the Atlantic Ocean by Irish migrants, including the landlords', the charities', the sailors', the British, US governments' viewpoints, to name but a few of that myriad of qualifying perspectives on transoceanic voyage in the $19^{\text {th }}$ century, from the British isles to Canada or Australia... As a reliable historian, McMahon reminds us that hardly three percent of the total number of Irish emigrants actually died at sea, as explained page 158-160. But McMahon promptly adds that theses statitics should not "demean or debase the suffering of those who fell ill and died in 1847" (p. 160). The year 1847 remains the actual annus horribilis in the period, especially amongst the Irish emigrants who sailed to Quebec and Grosse Isle, with outstanding nightmarish instances, "horror ships" such as the Virginius and the Avon. McMahon reminds us that over half the passengers of the Avon were lost after leaving Cork. Let us note in passing that the 15-page-long index, notes and bibliographical references are plentiful but always insightful and useful to identify the sources used throughout this book, which often looks like a carefully documented fresco of the psychological ordeals - and substantilly rarer moments of joy or relief - Irish voyagers went through.

Most studies actually focus on what happened in the island of Ireland - that is on the ground - and while paying extra attention to emigration to America or Down Under as regards convicts, they do not describe thoroughly what actually happened between the moment the people who could afford it by their own means or thanks to charity or due to strict law enforcement actually left Ireland and the moment when they possibly landed - or not, as implied in the title of the book under scrutiny here. Precisely, this book by Cian T. McMahon purports to explore the whole process of trying to reach what was often felt as a "land of strangers and of strange customs" (p. 194) to fly away from that "poverty isle" (p. 15) that was Ireland at the time. The book logically falls into five chapters describing the different stages of the voyage: 1. Preparation, 2. Embarkation, 3. Life, 4. Death, 5. Arrival (dead or alive as long as your body had not been hurriedly dumped into the depths of the ocean due to the rapid spread of various infections aboard).

The original quality of the book stands out in that it is widely based upon the actual letters exchanged between those who emigrated to the United States (or Canada) or were forced to join a penal colony in Australia, from Ireland, from the mid-1840s to the mid-1850s. Letters are quoted extensively through a host of fragments that are traced and documented in final notes that span over thirty pages. As McMahon explains himself in his essay on sources and methodology (p. 243248), his endeavour to understand "how Irish emigrants thought and talked about the voyage process during the Great Famine required working with a wide range of 
primary and secondary sources on multiple continents" (p. 243). That the author should feel the need to insert this final essay reminds us that History remains among the humanities, a science of the fragment that seeks to reconstruct the past as faithfully as possible, while acknowledging the usual limitations of the representations of events, be they based upon dry statistics, or more subjective testimonies. Hence the format of the book per se raises epistemological and methodological issues due to the hybrid object under scrutiny that oscillates between facts and the subjective representations of the same - more or less attainable and representable - facts through epistolary exchanges.

To cut a long story short, the great force of this highly readable book is that it individuates the usually great mass of Irish migrants, giving them back (partly but undeniably) their voices - frequently including their erratic spelling and idiomatic grammar -, - some of - their names and singular itineraries through life. It also allows the contemporary reader to draw parallels and devise a pattern of connections and repetitions in human history. In that respect, let us quote:

Compared to twenty-first-century air travel, their [i.e. Irish migrants'] voyages were dangerous and on a par with those faced by African migrants on the Mediterranean today. (p. 160)

In a word, the book underlines the wider framework, the bigger violent picture and the subtle cogwheels of global networks of interconnections that human history is based upon. Through this singular process of analysis of letters, "low-resolution refugees" (p. 238) of the past - and the present at that - may be seen as human individuals once again. No doubt this book will make a durable contribution to the increasingly important scientific field of migration studies.

Thierry RoBIN

\section{Jeffrey Dudgeon, H. Montgomery Hyde: Ulster Unionist MP, Gay Law Reform Campaigner and Prodigious Author, Belfast, Belfast Press, 2018, 56 p.}

The recent and somewhat chaotic decision to replace Arlene Foster with Edwin Poots, and his subsequent rejection in favour of Sir Jeffrey Donaldson MP, as the leader of the Democratic Unionist Party (DUP) has once again brought into sharp focus the social conservatism of the party and its membership. This was increased when he and the deputy leader of the DUP, Paula Bradley MLA, offered an apology for the homophobia previously displayed by the party and its membership. Whilst some have welcomed it as a significant moment, others have regarded it with more caution. It has been noted that this apology did not apologise directly for the comments made by Ian Paisley Jr. MP and former DUP MP, Iris Robinson. Further there was no apology or admonishment for the DUP founder, the Reverend Dr. Ian Paisley or his Save Ulster from Sodomy campaign. 